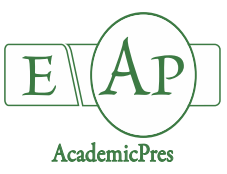

Onache AP et al. (2021)

Notulae Botanicae Horti Agrobotanici Cluj-Napoca

Volume 49, Issue 2, Article number 12349

DOI: $10.15835 /$ nbha49212349

Research Article

\title{
Comparison of some DNA extraction methods from monovarietal must and wines
}

\section{Anca P. ONACHE, Adriana BĂDULESCU, Anamaria M. DUMITRU, Dorin I. SUMEDREA, Carmen F. POPESCU*}

\author{
National Research and Development Institute for Biotechnology in Horticulture, Ștefăneşti, Calea Bucureşti, Piteşti, 37, Ștefăneşti, \\ Argeş,Romania; anca27il@yahoo.com; badulescuadriana18@yahoo.com; anamaria.ilina@yahoo.com; dsumedrea@yahoo.com; \\ carm3n_popescu@yahoo.com (*correspondingauthor)
}

\begin{abstract}
The methods applied for DNA extraction from must and wine samples with monovarietal origin are presented and discussed aiming to prove the quality of extracted DNA and its good properties for further use in molecular tests. In the present research were compared four different DNA extraction methods from must and wine samples obtained from eleven $V$. vinifera varieties (five grapevine varieties for white wines and six grapevine varieties for red wines, respectively). Taking into consideration the amounts of obtained DNA, the concentrations and purities of the final DNA extracts, were stood out two modified methods. For all must samples, very efficient was the second method, which allowed obtaining a mean value of $87.9 \mathrm{ng}^{-1} \mathrm{l}^{-1}$ for the DNA concentration with 1.55 purity. Among the tested procedures, for monovarietal wine samples, the fourth method proved to be the most efficient which brought a mean value of $64.7 \mathrm{ng} \mathrm{\mu l}^{-1}$ for DNA concentration with 1.66 purity. This method adequate for wine samples involves two CTAB solution treatments and the RNase treatment applied before DNA resuspension. The DNA from must and wine extracts and the DNA from leaves of the corresponding grapevine varieties were amplified with five specific microsatellite primers (VVS2, VVMD27, VVMD32, VrZAG79 and VrZAG62). The aspects of pattern profiles were analysed in parallel and proved that the extracted DNA was suitable for amplification with these specific $V$. vinifera primers. The two selected extraction procedures are considered good for research purposes and ensure obtaining of good-quality extracted DNA from musts and one-year old wines.
\end{abstract}

Keywords: DNA quality; grapevine; spectrophotometry; SSR markers; traceability

\section{Introduction}

In countries with tradition of grapevine growing, checking the quality of wines, proving their origin and authenticity before marketing are priority concerns. In accordance with Directive 2000/13/EC and up-to-date national legislation, all stages of the agri-food supply chain must be monitored through a traceability system. The quality of any food product first of all depends on its origin and the accurate identification of the variety / varieties from which that product was obtained (Siret et al., 2000). Reliable methods of traceability along the entire chain, from the vineyard plant to the wine in the bottle, have been improved during the last 20 years on

Received: 22 Apr 2021. Received in revised form: 26 May 2021. Accepted: 28 May 2021. Published online: 04Jun 2021.

From Volume 49, Issue 1, 2021, Notulae Botanicae Horti Agrobotanici Cluj-Napoca journal uses article numbers in place of the traditional method of continuous pagination through the volume. The journal will continue to appear quarterly, as before, with four annual numbers. 
the base of new analysis methods development that meet the legislative requirements and respond to demands for the wine market (Savazzini and Martinelli, 2006).

The need for molecular techniques to analyse the grapevine-derived products, such as musts and wines, has been the subject of several studies (Nakamura et al., 2007; Drábek et al., 2008; Pereira et al., 2011; Bigliazzi et al., 2012). In recent years, advances in the molecular analysis of residual amounts of nucleic acids obtained from musts or wines, have brought information about the genotyping of wines or proof of their origin from a particular variety (Gheorghe et al., 2010; Catalano et al., 2016; Pereira et al., 2017).

The first step for any molecular analysis is to obtain a good quality DNA. Progress has been made in extracting DNA from must and wine samples, and various protocols have been developed by Faria et al. (2000), Siret et al. (2000) and Garcia-Beneytez et al. (2002). Comparatively analysed to evaluate the quality of the obtained extracts from grape juice, must, or experimental wines during and after fermentation were published by Savazzini and Martinelli (2006), Baleiras-Couto and Eiras-Dias (2006), Drabek et al. (2008), Briciu et al. (2010). After extraction, the DNA with good parameters of quality was used as template for grapevine varietal identification. Genotyping with SSR (simple sequence repeats) markers allowed the identification of varietyspecific alleles in the case of mono-varietal musts/wines, or identification of possible grapevine varieties used for experimental, or marketed wines (Baleiras-Couto and Eiras-Dias, 2006; Nakamura et al., 2007; Harta et al., 2011; Scali et al., 2014). Analysis of chloroplast DNA and microsatellite loci (cpSSR), considered an alternative approach to the varietal genetic identification of must and wine samples, was also attempted to prove their origin from Vitis vinifera L. genotypes (Arroyo-Garcia et al., 2002; Agrimonti and Marmiroli, 2018; Oganesyants et al., 2018).

Varietal authentication of wines using amplification of wine genomic residual DNA with SSR markers is considered an important tool for Wine DNA Fingerprinting. Today, the use of resulted databases in association with dedicated bioinformatics are considered essential tools on wine quality and its compositional profile (Vignani et al., 2019).

Currently, advances in sequencing technologies have allowed the widespread use of SNP (Single Nucleotide Polymorphisms) markers to identify differences among grapevine varieties (Cabezas et al., 2011). Although is a relatively expensive technique, the use of such markers is suitable for determinations with lowquality DNA (as is often obtained by DNA extraction from must and wine samples). The great advantage of this molecular genetic approaches is the highlighting of $V$. vinifera genotypes in mono- or multi-varietal wine samples, including the quantification of each variety in the mixture (Lazareva et al., 2020).

All these research articles emphasised on the difficulties encountered in extracting DNA from must, young or aged wine samples. Although efficient methods have been established for the extraction of DNA from the tissues of grapevine plants (Lodhi et al., 1994), the extraction of DNA from grapevine-derived products need nevertheless be improved and simplified. The main aspects necessary to be overcome are the insufficient quantity and quality of the final DNA extract and especially its interference with polysaccharides, polypeptides, or polyphenols during the applied extracted protocols.

Aiming to contribute to overcome these undesired aspects, this study presents the methods tested for DNA extraction from must and wine samples with monovarietal origins, selection of the most efficient methods and the main properties of obtained DNA necessary for further PCR (polymerase chain reaction) analyses-based on molecular markers. The described approach could be a part of the traceability methodology possible useful to guarantee the origin from Vitis vinifera of winemaking products.

\section{Materials and Methods}

Different extraction methods were tested to obtain DNA from plant material (young leaves), monovarietal must and one-year old monovarietal wines. Plant material, must and wines belonging to five grapevine varieties for white wines ('Sauvignon blanc', 'Italian Riesling', 'Fetească regală', 'Chardonnay' and 
'Muscat Ottonel') and six grapevine varieties for red wines ('Blauer Zweigelt', 'Burgund', 'Fetească neagră', 'Merlot', 'Cabernet Sauvignon' and 'Pinot noir') were selected to be analysed. The plant material was harvested from ex situ collection and used immediately for DNA extraction, while the samples of must and wine were stored in the refrigerator at $2{ }^{\circ} \mathrm{C}$ until DNA extraction.

\section{Methods for DNA extraction from leaves, must and wine samples}

Young leaves belonging to the eleven varieties were cut in small pieces and crushed with glass pistil against the tube walls. For cell lysis were added $750 \mu \mathrm{l}$ lysis buffer, $25 \mu \mathrm{l}$ of $20 \%$ sodium-dodecyl sulphate, 40 mg polyvinylpyrrolidone and $4 \mu \mathrm{l}$ RNase, homogenized and incubated at $65^{\circ} \mathrm{C}$ in water bath for 60 minutes. For precipitation of proteins and polysaccharides were used $400 \mu \mathrm{l}$ of phenol:chloroform:isoamyl alcohol (25:24:1). After centrifugation the upper aqueous phase was collected into a new microfuge tube, added an equal volume of Tris EDTA, mixed gently by pipetting. After centrifugation it was repeated the removing of the impurities with Tris EDTA and ethanol. The deposited DNA was air dried at room temperature for 30 minutes and dissolved in elution buffer.

The must and wine samples were subjected to different procedures as shown in Table 1 . The tested methods were selected from the literature, and the methodology applied was adapted according to the working possibilities in our laboratory. The four methods tested were:

- Method 1: Qiagen DNeasy Plant Kit, with adequate sample preparation for Vitis vinifera L.

- Method 2: based on Savazzini and Martinelli (2006) method with few modifications.

- Method 3 which is a combination of the two previous methods: preparation of samples and lysis according to the first method, while precipitation of proteins, polysaccharides and detergent, separation of DNA from other compounds and resuspension of DNA according to the second one.

- Method 4: based on Işçi et al. (2014) method with few modifications.

The modifications mentioned above refer to: the quantities/volumes of chemical compounds, their concentrations, centrifugal speeds-durations-temperatures at which the centrifugations were performed or added step in protocol.

\section{DNA quantification and quality}

The quantity and quality of the DNA obtained from each extraction approach (from leaves, must or wine) were determined with the BioPhotometer plus (Eppendorf, DE). All extractions were done in three repetitions. The differences among the four methods were analysed with Duncan test aiming to reveal the "significant" differences at the significant level of $\leq 0.05$.

\section{Microsatellite amplification}

Analyses of microsatellite loci VVS2, VVMD27, VVMD32, VrZAG79 and VrZAG62 were carried out in a thermal cycler TC-512 (Techne, Duxford, Cambridge, UK). The PCR program for DNA samples were as follows: initial denaturation at $94^{\circ} \mathrm{C} / 3 \mathrm{~min}$, followed by 35 cycles with denaturation at $95^{\circ} \mathrm{C}$ for $20 \mathrm{~s}$, or $30 \mathrm{~s}$, annealing temperature of $55^{\circ} \mathrm{C}$, or $61^{\circ} \mathrm{C}$ for $30 \mathrm{~s}$, elongation at $72{ }^{\circ} \mathrm{C}$ for $30 \mathrm{~s}$, and a final extension step at 72 ${ }^{\circ} \mathrm{C}$ for 6 min and kept at $4{ }^{\circ} \mathrm{C}$. The PCR program for DNA samples of must and wines, was a two-step amplification ( 35 cycles followed by another 40 cycles) with the same programme, similar to the procedure recommended by Siret et al. (2.000). For PCR reactions were used: $4 \mu \mathrm{l}$ of 5x FirePol Master Mix Ready to load (Solis BioDyne, Estonia), $3 \mu \mathrm{l}$ DNA template, $2 \mu \mathrm{l}$ of forward and $2 \mu \mathrm{l}$ reverse primer, and water to a total volume of $25 \mu \mathrm{l}$. In the case of two-step amplification, $5 \mu \mathrm{L}$ of the first PCR amplification was transferred into the second PCR reaction mix.

The amplification products were visualized after horizontal electrophoresis in 3.0\% agarose gel with TAE buffer, and stained with ethidium bromide. The gels were photographed with Gene Flash Syngene Bio Imaging system under UV light. GeneRuler of 100 bp DNA Ladder (Solis BioDyne) was used as a molecular weight marker. 
Table 1. Methods for DNA extraction from must and wine samples

\begin{tabular}{|c|c|c|c|}
\hline Method 1. Kit Qiagen & $\begin{array}{l}\text { Method 2. Savazzini and } \\
\text { Martinelli (2006) modified }\end{array}$ & Method 3. Combined method & $\begin{array}{l}\text { Method 4. Işçi et al. (2014) } \\
\text { modified }\end{array}$ \\
\hline \multicolumn{4}{|c|}{ Preparation of the must and wine samples } \\
\hline $\begin{array}{l}100 \mathrm{ml} \text { of must/wine is centrifuged at } \\
5,500 \mathrm{rpm}, 15 \mathrm{~min} \text {; the pellet is used } \\
\text { further on. }\end{array}$ & $\begin{array}{l}45 \mathrm{ml} \text { of must/wine sample is } \\
\text { homogenized with } 5 \mathrm{ml} \text { of } \mathrm{NaCl} \\
(5 \mathrm{M}) \text { and stored at }+2{ }^{\circ} \mathrm{C} \text { for } \\
24-48 \text { hours; the samples are } \\
\text { centrifuged at } 5,500 \mathrm{rpm}, 30 \mathrm{~min} \\
\text { and } 4{ }^{\circ} \mathrm{C} \text {; the liquid phase is } \\
\text { discarded. }\end{array}$ & $\begin{array}{l}10 \mathrm{ml} \text { of sample is centrifuge at } \\
5,500 \mathrm{rpm}, 15 \mathrm{~min} \text {; the solid } \\
\text { phase (pellet) is subsequently } \\
\text { used. }\end{array}$ & $\begin{array}{l}45 \mathrm{ml} \text { of the sample is } \\
\text { homogenized with } 5 \mathrm{ml} \text { of } \\
\mathrm{NaCl}(1,2 \mathrm{M}) \text { and stored at - } \\
20^{\circ} \mathrm{C} \text { for one week; the } \\
\text { samples are centrifuged at } \\
6,000 \mathrm{rpm}, 30 \text { min and } 4{ }^{\circ} \mathrm{C} \text {; } \\
\text { the liquid phase is discarded. }\end{array}$ \\
\hline \multicolumn{4}{|c|}{ Resuspension and homogenization } \\
\hline $\begin{array}{l}\text { Add: } 4 \mu \mathrm{l} \text { RNase }+400 \mu \mathrm{l} \text { lysis buffer }+ \\
1 \mu \mathrm{l} 2 \text {-mercaptoethanol }+50 \mathrm{mg} \\
\text { polyvinylpyrrolidone. }\end{array}$ & $\begin{array}{c}\text { Add: } 4 \mu \mathrm{l} \text { RNase }+750 \mu \mathrm{l} \\
\text { CTAB buffer [25 mM EDTA, } 1 \\
\text { M Tris-HCl, } 2 \mathrm{M} \mathrm{NaCl}, 3 \% \\
\text { CTAB, } 8 \mathrm{pH}]+2 \mu \mathrm{l} 2- \\
\text { mercaptoethanol }+80 \mathrm{mg} \\
\text { polyvinylpyrrolidone. }\end{array}$ & $\begin{array}{c}\text { Add: } 4 \mu \mathrm{l} \text { Rase }+400 \mu \mathrm{l} \text { lysis } \\
\text { buffer }[20 \mathrm{mM} \text { EDTA }+100 \\
\text { mM Tris- } \mathrm{HCl}, 1.4 \mathrm{M} \mathrm{NaCl} \text {, } \\
2 \% \mathrm{CTAB}, 8 \mathrm{pH}]+1 \mu \mathrm{l} 2- \\
\text { mercaptoethanol } \\
+50 \mathrm{mg} \text { polyvinylpyrrolidone. }\end{array}$ & $\begin{array}{l}\text { Add to the pellet: } 750 \mu \mathrm{l} \\
\text { CTAB buffer }+1.6 \mu \mathrm{l} 2 \text { - } \\
\text { mercapto-ethanol }+80 \mathrm{mg} \\
\text { polyvinylpyrrolidone }+1 \mu \mathrm{l} \\
\text { proteinase } \mathrm{K} .\end{array}$ \\
\hline \multicolumn{4}{|c|}{ Cell lysis of the pellet by incubation } \\
\hline \multirow{2}{*}{\multicolumn{4}{|c|}{$\begin{array}{c}\text { The samples were mixed very well and incubated at } 65^{\circ} \mathrm{C} \text { in water bath for } 60 \text { minutes; from time to time the samples were homogenized by vortex } \\
\text { Precipitation of proteins, polysaccharides and detergent }\end{array}$}} \\
\hline & & & \\
\hline $\begin{array}{l}\text { Add } 130 \mu \mathrm{l} \text { of precipitation buffer to the } \\
\text { lysate, vortex and incubate the samples } \\
\text { for } 5-15 \mathrm{~min} \text {. on ice; centrifugation at } \\
14,000 \mathrm{rpm}, 5 \mathrm{~min} \text {. }\end{array}$ & \multicolumn{3}{|c|}{$\begin{array}{l}\text { Add one volume of phenol-chloroform-isoamyl alcohol }(25: 24: 1) ; \text { mix the contents by inverting the } \\
\text { tubes for } \approx 3 \mathrm{~min} \text {; centrifugation at } 14,000 \mathrm{rpm}, 5 \mathrm{~min} \text {. }\end{array}$} \\
\hline \multicolumn{4}{|c|}{ Separation of DNA from other compounds } \\
\hline $\begin{array}{l}\text { The supernatant is passed through the } \\
\text { separating column attached to a } 2 \mathrm{ml} \\
\text { collection tube; centrifugation at } 14,000 \\
\text { rpm, } 2 \text { min; determine the amount of } \\
\text { the obtained lysate. }\end{array}$ & \multicolumn{2}{|c|}{$\begin{array}{l}\text { The liquid phase is transferred to a new tube; repeat the extraction } \\
\text { with phenol-chloroform-isoamyl alcohol }(25: 24: 1) \text { in the same } \\
\text { amount and centrifugation at } 14,000 \mathrm{rpm}, 5 \mathrm{~min} \text {. }\end{array}$} & $\begin{array}{c}\text { The liquid phase is } \\
\text { transferred to a new tube; add } \\
4 \mu \mathrm{l} \text { RNase, } 0.1 \text { volume of } \\
10 \% \mathrm{CTAB} \text {; maintain the } \\
\text { mix at } 37^{\circ} \mathrm{C} \text { for } 30 \mathrm{~min} \text {; } \\
\text { centrifugation at } 14,000 \mathrm{rpm} \text {, } \\
5 \mathrm{~min} .\end{array}$ \\
\hline \multicolumn{4}{|c|}{ DNA resuspension } \\
\hline $\begin{array}{l}\text { Add } 1.5 \text { volumes of DNA binding } \\
\text { buffer to the mixture lysate; stir by } \\
\text { pipetting. }\end{array}$ & \multicolumn{2}{|c|}{$\begin{array}{l}\text { Add to the liquid phase } 1 \text { volume of cold } 2 \text {-isopropanol and mix } \\
\text { gently by pipetting. }\end{array}$} & $\begin{array}{l}\text { Add to the liquid phase } 0.6 \\
\text { volume of cold 2-isopropanol. }\end{array}$ \\
\hline \multicolumn{4}{|c|}{ DNA precipitation } \\
\hline $\begin{array}{l}\text { Pass the solution through the colourless } \\
\text { column attached to the } 2 \mathrm{ml} \text { collection } \\
\text { tube; spin at } 9,000 \mathrm{rpm}, 1 \mathrm{~min} \text {. }\end{array}$ & $\begin{array}{l}\text { Incubate at }-20^{\circ} \mathrm{C} \text { for } 30 \mathrm{~min} \text {; } \\
\text { centrifugation at } 14,000 \mathrm{rpm}, 5 \\
\text { min. }\end{array}$ & $\begin{array}{l}\text { Place the tubes at }-20{ }^{\circ} \mathrm{C} \text { for } 60 \\
\text { min; } \\
\text { centrifugation at } 14,000 \mathrm{rpm}, 5 \\
\text { min. }\end{array}$ & $\begin{array}{l}\text { Incubate at }-20^{\circ} \mathrm{C} \text { overnight; } \\
\text { centrifugation at } 14,000 \mathrm{rpm} \text {, } \\
30 \mathrm{~min} .\end{array}$ \\
\hline \multicolumn{4}{|c|}{ DNA washing } \\
\hline $\begin{array}{l}\text { The column is placed in a new } \\
\text { collection tube; add } 500 \mu \mathrm{l} \text { wash buffer, } \\
\text { centrifugation at } 9,000 \mathrm{rpm}, 1 \mathrm{~min} \text {; } \\
\text { repeat the wash; centrifugation at } \\
14,000 \mathrm{rpm}, 2 \mathrm{~min} \text {. }\end{array}$ & \multicolumn{3}{|c|}{$\begin{array}{l}\text { Discard the supernatant; the pellet is washed with } 70 \% \text { ethanol for } 30 \mathrm{~min} \text {. and centrifugation at } 9,000 \\
\text { rpm, } 1 \text { min; repeat the wash with } 70 \% \text { ethanol of the pellet and centrifugation; leave the tubes } \\
\text { uncovered for } 30 \text { min. to evaporate the alcohol or leave the tubes upside down on a filter paper until } \\
\text { the next day. }\end{array}$} \\
\hline \multicolumn{4}{|c|}{ Elution of the DNA } \\
\hline $\begin{array}{l}\text { Transfer the column to a } 1.5 / 2 \mathrm{ml} \text { tube; } \\
\text { add } 50 \mu \text { l of elution buffer directly to } \\
\text { the filter membrane; incubate for } 5 \mathrm{~min} \text {. } \\
\text { at room temperature; centrifugation at } \\
9,000 \mathrm{rpm}, 1 \mathrm{~min} \text {; repeat the wash of the } \\
\text { membrane with another } 50 \mu \mathrm{l} \text { of elution } \\
\text { buffer. }\end{array}$ & \multicolumn{3}{|c|}{$\begin{array}{l}\text { The deposited DNA is dissolved in 50-100 } \mu \text { l of elution buffer, or in double distilled water for further } \\
\text { use (to evaluate the quantity and quality of the extracted DNA). }\end{array}$} \\
\hline
\end{tabular}




\section{Results and Discussion}

The procedures for obtaining wines include multiple and different steps depending on the type of wine to be obtained. The main stages, common to all types of wines, are crushing, pressing, fermentation, filtration, finishing and aging. Each of these stages affects the quality and quantity of DNA from the plant material of origin, namely grapes. Numerous articles have shown the limits of DNA extraction methods depending on the composition of the wines; for example, in red wines are present tannins and polysaccharides that could be responsible for DNA impurity (Garcia-Beneytez et al., 2002, Siret et al., 2002).

The selected methods to be tested in our laboratory took into consideration the properties and roles of the reagents: $\mathrm{CTAB}$ (cetyl trimethylammonium bromide) which dissolve the membranes and increase the DNA precipitation; Tris- $\mathrm{HCl}$ and EDTA inhibit DNase; 2-mercapto-ethanol eliminates the polyphenols and facilitates protein denaturation; polyvinylpyrrolidone eliminates polysaccharides; proteinase $\mathrm{K}$ determines chromatin proteins separation; phenol-chloroform-isoamyl alcohol promotes the separation of lipids and cellular debris into the organic phase, and also separation of DNA into the aqueous phase.

\section{Preparation of the must and wine samples}

For the four DNA extraction tested methods, different amounts of samples (must/wine) were used. These initial amounts of sample and how the samples are treated during the applied procedures play an important role for the concentrations of DNA resulted at the end. According to our results presented in Table 2 and Table 3 , a much lower concentration $\left(\mathrm{ng} \mathrm{\mu l}^{-1}\right)$ of DNA is obtained if is started from a smaller amount of must/wine (method 3), or if the protocol involved the use of mini-filter columns (method 1$)$.

Table 2. Comparison of the four tested DNA extraction methods for must samples: average values for DNA concentration and purity

\begin{tabular}{|c|c|c|c|c|c|c|c|c|}
\hline Method & \multicolumn{2}{|c|}{ Method 1} & \multicolumn{2}{|c|}{ Method 2} & \multicolumn{2}{|c|}{ Method 3} & \multicolumn{2}{|c|}{ Method 4} \\
\hline Must sample & $\begin{array}{l}\text { DNA } \\
\mathrm{ng} \mu l^{-1}\end{array}$ & $\begin{array}{c}260 / 280 \\
\text { ratio }\end{array}$ & $\begin{array}{l}\text { DNA } \\
n g \mu l^{-1}\end{array}$ & $\begin{array}{c}260 / 280 \\
\text { ratio }\end{array}$ & $\begin{array}{l}\text { DNA } \\
{\mathrm{ng} \mu l^{-1}}\end{array}$ & $\begin{array}{c}260 / 280 \\
\text { ratio }\end{array}$ & $\begin{array}{l}\text { DNA } \\
n g \mu l^{-1}\end{array}$ & $\begin{array}{c}260 / 280 \\
\text { ratio }\end{array}$ \\
\hline 'Sauvignon blanc' & 22.3 & 1.58 & 49.5 & 1.49 & 18.3 & 1.21 & 55.6 & 1.46 \\
\hline 'Riesling' & 12.1 & 1.71 & 126.9 & 1.56 & 92.5 & 1.33 & 102.4 & 1.31 \\
\hline 'Feteasca regala' & 60.6 & 1.73 & 117.3 & 1.60 & 69.0 & 1.32 & 99.6 & 1.31 \\
\hline 'Chardonnay' & 36.2 & 1.43 & 72.6 & 1.40 & 28.3 & 1.27 & 68.9 & 1.31 \\
\hline 'Blauer Zweigelt' & 47.1 & 1.71 & 123.2 & 1.62 & 37.8 & 1.41 & 59.7 & 1.09 \\
\hline 'Burgund' & 15.5 & 1.44 & 76.4 & 1.47 & 44.3 & 1.23 & 76.9 & 1.09 \\
\hline 'Feteasca neagra' & 55.1 & 1.64 & 98.3 & 1.67 & 55.2 & 1.34 & 83.2 & 1.14 \\
\hline 'Merlot' & 26.7 & 1.68 & 54.3 & 1.62 & 33.7 & 1.37 & 65.0 & 1.18 \\
\hline 'Pinot noir' & 17.9 & 1.55 & 42.8 & 1.58 & 39.2 & 1.23 & 50.1 & 1.14 \\
\hline $\begin{array}{l}\text { 'Cabernet } \\
\text { Sauvignon' }\end{array}$ & 53.4 & 1.89 & 104.6 & 1.61 & 35.3 & 1.21 & 76.1 & 1.16 \\
\hline 'Muscat Ottonel' & 18.5 & 1.67 & 101.4 & 1.48 & 55.1 & 1.37 & 77.2 & 1.37 \\
\hline Mean & $33.22 \mathrm{~b}$ & $1.64 \mathrm{a}$ & $87.93 \mathrm{a}$ & $1.55 \mathrm{~b}$ & $46.24 \mathrm{~b}$ & $1.30 \mathrm{c}$ & $74.06 \mathrm{a}$ & $1.23 \mathrm{c}$ \\
\hline $\begin{array}{l}\text { Standard } \\
\text { deviation }\end{array}$ & \pm 17.91 & \pm 0.13 & \pm 30.34 & \pm 0.08 & \pm 20.78 & \pm 0.07 & \pm 16.70 & \pm 0.12 \\
\hline
\end{tabular}

Method 1: Kit Qiagen; Method 2: Savazzini and Martinelli (2006) modified; Method 3: Combined method; Method 4: Işçi et al. (2014) modified

Based on the Duncan test $(P \leq 0.05)$, the mean values for each method (with eleven different samples, each one in three replicates) followed by different letters are significant different, while the values followed by the same letter are not statistically different.

Precipitation of the must and wine samples with $5 \mathrm{M}$ sodium chloride at $2{ }^{\circ} \mathrm{C}$ for $24-48 \mathrm{~h}(\operatorname{method} 2)$, or with $1.2 \mathrm{M}$ sodium chloride at $-20^{\circ} \mathrm{C}$ for one week (method 4 ), seemed to have good influence for the DNA final concentration. In both cases, the mean registered values for all eleven samples were significant higher (between 74.06 and $87.93 \mathrm{ng} \mathrm{\mu l}^{-1}$ for must samples and between 57.4 and $64.72 \mathrm{ng} \mathrm{\mu l}^{1-1}$ for wine samples) in comparison with the other two methods for which were used untreated must, or wine samples. Our results are similar and confirmed the previous conclusions stated by Savazzini and Martinelli (2006), Pereira et al. (2011) 
and Oganesyants et al. (2018) regarding the importance of pretreatment of must and wine samples with sodium chloride before DNA extraction.

Table 3. Comparison of the four tested DNA extraction methods for wine samples: average values for DNA concentration and purity

\begin{tabular}{|c|c|c|c|c|c|c|c|c|}
\hline Method & \multicolumn{2}{|c|}{ Method 1} & \multicolumn{2}{|c|}{ Method 2} & \multicolumn{2}{|c|}{ Method 3} & \multicolumn{2}{|c|}{ Method 4} \\
\hline Wine sample & $\begin{array}{l}\text { DNA } \\
\mathrm{ng} \mu \mathrm{l}^{-1}\end{array}$ & $\begin{array}{c}260 / 280 \\
\text { ratio }\end{array}$ & $\begin{array}{l}\text { DNA } \\
\mathrm{ng} \mu^{-1}\end{array}$ & $\begin{array}{c}260 / 280 \\
\text { ratio }\end{array}$ & $\begin{array}{l}\text { DNA } \\
\mathrm{ng} \mu \mathrm{l}^{-1}\end{array}$ & $\begin{array}{c}260 / 280 \\
\text { ratio }\end{array}$ & $\begin{array}{l}\text { DNA } \\
\mathrm{ng} \mu \mathrm{l}^{-1}\end{array}$ & $\begin{array}{c}260 / 280 \\
\text { ratio }\end{array}$ \\
\hline 'Sauvignon blanc' & 18.0 & 1.21 & 64.7 & 1.57 & 28.2 & 1.21 & 89.0 & 1.60 \\
\hline 'Riesling' & 4.0 & 1.13 & 42.6 & 1.45 & 14.3 & 1.13 & 15.3 & 1.57 \\
\hline 'Feteasca regala' & 16.2 & 1.48 & 15.1 & 1.38 & 16.5 & 1.48 & 67.9 & 1.56 \\
\hline 'Chardonnay' & 28.3 & 1.27 & 72.6 & 1.40 & 20.7 & 1.21 & 36.0 & 1.53 \\
\hline 'Blauer Zweigelt' & 77.8 & 1.58 & 101.5 & 1.56 & 33.4 & 1.31 & 115.3 & 1.66 \\
\hline 'Burgund' & 33.1 & 1.20 & 39.7 & 1.55 & 86.8 & 1.53 & 107.9 & 1.72 \\
\hline 'Feteasca neagra' & 96.2 & 1.61 & 96.0 & 1.61 & 77.3 & 1.58 & 119.3 & 1.85 \\
\hline 'Merlot' & 26.4 & 1.47 & 114.7 & 1.42 & 47.0 & 1.42 & 74.6 & 1.56 \\
\hline 'Pinot noir' & 6.2 & 1.54 & 10.7 & 1.56 & 7.3 & 1.43 & 10.2 & 1.78 \\
\hline $\begin{array}{l}\text { 'Cabernet } \\
\text { Sauvignon' }\end{array}$ & 26.4 & 1.53 & 46.3 & 1.65 & 32.5 & 1.41 & 49.9 & 1.71 \\
\hline 'Muscat Ottonel' & 85.6 & 1.51 & 27.5 & 1.65 & 22.4 & 1.25 & 26.5 & 1.72 \\
\hline Mean & $38.02 \mathrm{~b}$ & $1.41 \mathrm{c}$ & $57.4 \mathrm{a}$ & $1.52 \mathrm{~b}$ & $35.13 \mathrm{~b}$ & $1.36 \mathrm{c}$ & $64.72 \mathrm{a}$ & $1.66 \mathrm{a}$ \\
\hline $\begin{array}{l}\text { Standard } \\
\text { deviation }\end{array}$ & \pm 32.66 & \pm 0.17 & \pm 35.38 & \pm 0.09 & \pm 25.63 & \pm 0.15 & \pm 40.02 & \pm 0.10 \\
\hline
\end{tabular}

Method 1: Kit Qiagen; Method 2: Savazzini and Martinelli (2006) modified; Method 3: Combined method; Method 4: Işçi et al. (2014) modified

Based on the Duncan test $(P \leq 0.05)$, the mean values for each method (with eleven different samples, each one in three replicates) followed by different letters are significant different, while the values followed by the same letter are not statistically different.

\section{Quantity and purity of the extracted DNA from monovarietal must and wine samples}

The data from spectrophotometric measurements gave us valuable information regarding the quantity and purity of the obtained DNA, and proved the possibility to obtain good genomic DNA, with high purity, from all extractions from monovarietal musts and wines. Besides the amount/concentration of the DNA in the final extract, it is very important the quality of this DNA, expressed by the ratio of absorbents A260/A280. If in the case of DNA extractions from plant tissues, the quantity and quality of DNA were very good (Table 4), in the case of must and wine samples such parameters were more difficult to be obtained and only after the application of some modifications in different stages of the extraction methods (Table 2 and Table 3 ). In general, the main cause that generate lower values for the 260/280 ratio (under 1.6) is the presence in the final extracts of some contaminants. If the phenol compounds are present in the final eluted DNA (due to an inefficient, or omission of the washing procedure), their maximum absorbance between $270-275 \mathrm{~nm}$, very close to that of DNA, will generate higher values for absorbance at $260 \mathrm{~nm}$, meaning misleading results (Akkurt, 2012). Because in the tested protocols the phenol compounds were used only for protein precipitation and were not used for DNA precipitation, we considered that no phenol contamination occurred and the registered values of the absorbance were correct and not overexpressed.

The same inconvenient could be in the case of other contaminants (polysaccharides, proteins, solvents and salts) which have a maximum absorbance at 280,270 and $230 \mathrm{~nm}$ respectively, close to that of DNA. These types of compounds could be present in the eluted solution due to their co-purification with DNA, or due their ligation to DNA during extraction protocol (Faria et al., 2000; Nazhad and Solouki, 2008). Often, the contaminants form stable bound with nucleic acid and affect the quality of gel migration bands. This could be a possible reason why with our DNA extracts, obtained at the end of the extraction protocols, were not visible low-weight DNA bands, or smear bands in the agarose gel.

The RNase treatment is an important step for DNA extraction and is used to remove the RNA from genomic DNA and to isolate a high-quality DNA. If the RNA would not be degraded by RNase, its presence in the final eluted DNA extract would generate a higher $260 \mathrm{~nm}$ absorbance value and would indicate an 
overestimated quantity of DNA (Lee and Jain, 2017). In our experiments were applied RNase treatments either before lysis (methods 1, 2 and 3), or after precipitation and separation of proteins, polysaccharides and detergent (method 4). All values obtained for A260/A280 ratio of the eluted DNA were lower than 1.8, meaning efficient action of the RNase, and no detectable RNA contamination in the final extracts.

Table 4. The DNA concentration $\left(\mathrm{ng} \mu^{l^{-1}}\right)$, yield of DNA (ng) and its purity obtained from young leaves

\begin{tabular}{|c|c|c|c|}
\hline Grapevine variety & $260 / 280$ ratio & DNA ng $\mu l^{-1}$ & DNA yield (ng) \\
\hline 'Sauvignon blanc' & 1.75 & 70.4 & 10,560 \\
\hline 'Riesling' & 1.75 & 51.6 & 2,580 \\
\hline 'Feteasca regala' & 1.70 & 31.2 & 3,120 \\
\hline 'Chardonnay' & 1.73 & 44.9 & 6,735 \\
\hline 'Blauer Zweigelt' & 1.82 & 92.5 & 23,125 \\
\hline 'Burgund' & 1.78 & 52.5 & 7,875 \\
\hline 'Feteasca neagra' & 1.82 & 71.3 & 3,565 \\
\hline 'Merlot' & 1.76 & 89.0 & 22,250 \\
\hline 'Pinot noir' & 1.89 & 53.5 & 5,350 \\
\hline 'Cabernet Sauvignon' & 1.71 & 75.3 & 11,295 \\
\hline 'Muscat Ottonel' & 1.81 & 78.7 & 7,870 \\
\hline
\end{tabular}

Comparing the results obtained and presented in Table 2 for must samples, method 2 proved to be the most effective due to the concentration of DNA $\left(87.9 \mathrm{ng} \mathrm{ul}^{-1}\right)$ and a relatively good purity $(1.55)$ of the obtained extracts. In the case of monovarietal wine samples (Table 3), the method 4, with two steps of treatment with $\mathrm{CTAB}$, was the most efficient (mean value for DNA concentration of $64.7 \mathrm{ng} \mathrm{l}^{-1}$ and mean value for DNA purity of 1.66). Among the varieties, more difficult was to obtain good-quality and enough quantities of DNA extracts with 'Sauvignon blanc', 'Italian Riesling', 'Chardonnay', 'Merlot' and 'Pinot noir'.

When the protocol recommended by Qiagen was used with must samples, even if it resulted in obtaining the lowest concentration of DNA (33.22 $\left.\mathrm{ng} \mathrm{\mu l}^{-1}\right)$, its quality was the highest one (1.64). In contrast, in the case of wine samples, the results showed that this method is not appropriate.

\section{Amplification with SSR markers of the genomic DNA from must and wine samples}

The spectrophotometric measurements of the final eluted DNA from must and one-year-old wine samples (the quantity and purity of DNA) were the main criteria for the selection of the DNA samples used in analysis with microsatellite markers. Considering that for food-products a good-quality DNA, suitable for molecular analysis, has a A260/A280 ratio between 1.6 and 1.8, were selected and used further on only the samples with the highest purity values (among the samples of extracted DNA from the three replicates of each must and wine used in our experiments).

For grapevine, the basic characterization with nine 'standard' loci (VVS2, VVMD5, VVMD7, VVMD25, VVMD27, VVMD28, VVMD32, ssrZAG62 and ssrZAG79) proposed by the GrapeGen06 consortium and European Vitis Database (http://www.euvitis.de) is internationally accepted as tool for accessions' identity. Five of these SSR markers were tested with the eleven must and wine samples aiming to confirm the grapevine DNA origin of the must and wine extracts. The residual grape DNA obtained with method 2 (for monovarietal must samples) and method 4 (for monovarietal wine samples) were tested simultaneous with leaves DNA samples for amplifying with SSR primers.

PCR amplification of DNA samples in the presence of SSR primers could fail due to the small amount of DNA in the eluted solution or its possible degradation during storage. For the DNA samples from must and wine, different PCR methods, or different types of markers have been tried to overcome these problems (Savazzini and Martinelli 2006; Drábek et al., 2008). Similar aspects were noticed with our tested samples. The low DNA quantity in the final extract could be the main reason of either the lack of visible bands in agarose gel 
for the DNA samples obtained with the four methods, or the very weak, pale or blurred bands for most amplified products from must and wine samples after amplification with 35 cycles in the presence of SSR primers.

The two-step amplification ( 35 cycles followed by another 40 cycles) proved to be efficient for all DNA samples from monovarietal musts and wines. The amplicons generated with SSR primers were clearly visible in agarose gel (Figure 1) and was possible to compare the pattern profiles of must and wine with corresponding control cultivar (starting from DNA extracted from leaves). The images with amplification profiles for universal SSR primers proved that the DNA extraction methods and their PCR amplification were adequate, and the generated DNA fragments were specific for $V$. vinifera.

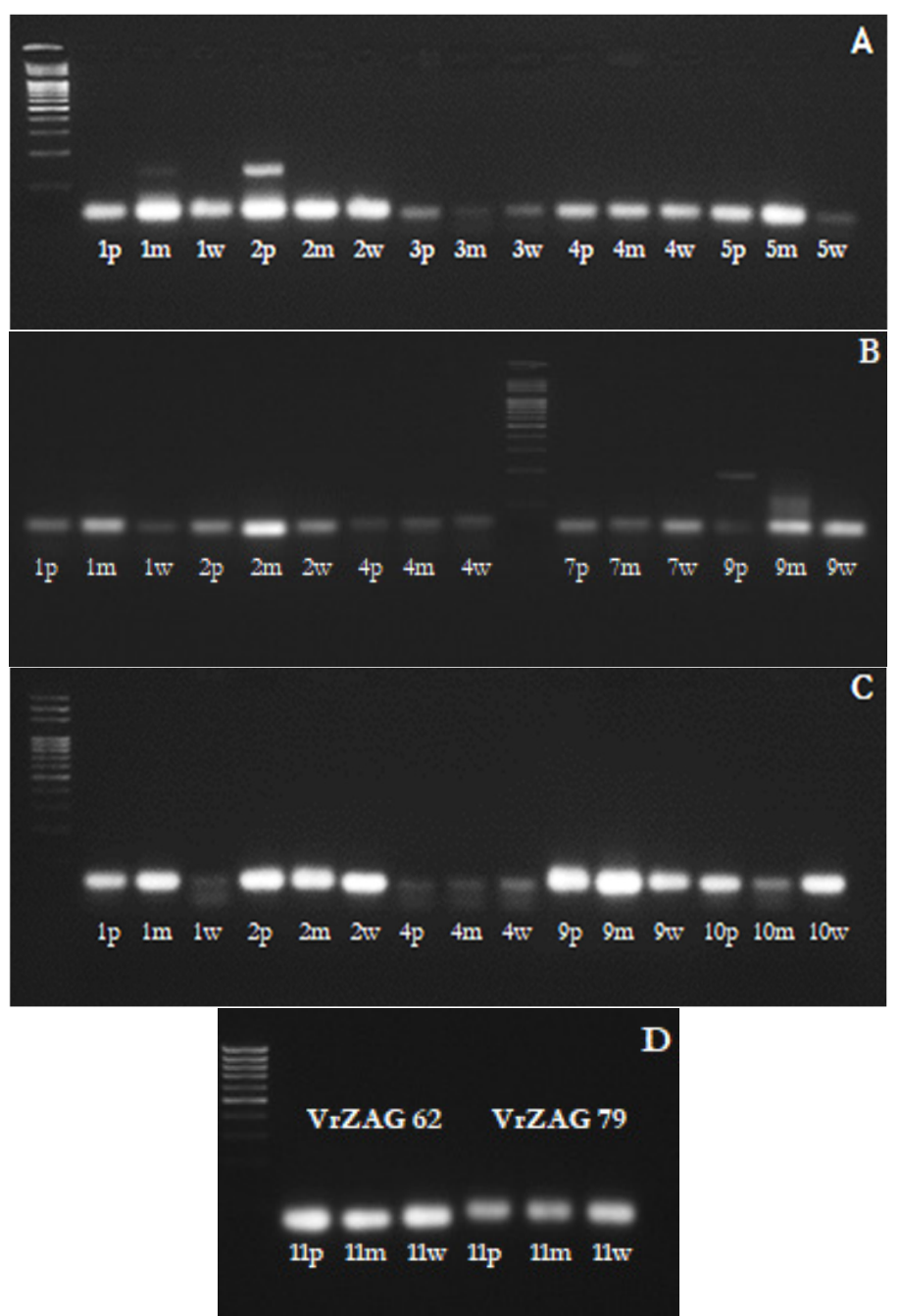

Figure 1. Amplified profiles with SSR primers: SSR2 (A), VVMD27 (B), and VrZAG62 (C), 'Muscat Ottonel' DNA amplified with VrZAG62 and VrZAG79 primers (D)

1 'Sauvignon blanc', 2 'Riesling', 3 'Fetească regală', 4 'Chardonnay', 5 'Blauer Zweigelt', 7 'Fetească neagră', 9 'Pinot noir', 10 'Cabernet Sauvignon', 11 'Muscat Ottonel'

$\mathrm{p}$ - leaf, $\mathrm{m}$ - must, w - wine 


\section{Conclusions}

For the selection of the most efficient methods applied in DNA extraction from must and wine samples, the concentration of the final extract and its quality are major criteria. Our results with four different methods showed that an amount of $45 \mathrm{ml}$ of must or wine and an initial precipitation with sodium chloride ensured a final extract with a good concentration of the residual DNA and in a sufficient amount for further investigations. Among the modified methods tested by us, in the case of monovarietal must samples the best results were obtained with modified Savazzini and Martinelli (2006) method, and in the case of monovarietal wine samples with the modified Işçi et al. (2014) method.

Ideally, a DNA isolation protocol should be fast, efficient, easy to perform, and yield sufficient highquality DNA to be adequate in molecular analyses. Our results proved the possibility of obtaining DNA from musts and wines with methods involving 6 and 24 hours of work, respectively (excepting the sample precipitation treatments), which are acceptable for research purposes. The DNA was present in the eluted solution and analysed with the microsatellite technique. The amplified products for one or two alleles were obtained with five microsatellite loci (specific for Vitis vinifera), thus bringing certainty for the grapevine origin of the analysed must and wine samples. But, for consumer food safety and next-generation sequencing applications, which require large number of samples processed in a short time, continuous improvements are needed for more efficient DNA extraction protocols and more accurate detection techniques for authentication of grapevine derived products such as commercial wines.

\section{Authors' Contributions}

CFP and APO: conceived and designed the experiments; CFP, APO and AMD: methodology; DIS: formal analysis; CFP, APO, AB, AMD and DIS: investigation; CFP, APO, AB and AMD: data curation; CFP: writing-review and editing; APO and AB: visualization; DIS: supervision; CFP: project administration; CFP, $\mathrm{AOP}$ and $\mathrm{AB}$ : funding acquisition. All authors read and approved the final manuscript.

\section{Acknowledgements}

This research article is based upon work from COST Action CA 17111 INTEGRAPE, supported by COST (European Cooperation in Science and Technology). This publication was financially supported by The Ministry of Agriculture and Rural Development through Projects ADER 7.2.6. and P.S.2.

\section{Conflict of Interests}

The authors declare that there are no conflicts of interest related to this article.

\section{References}

Agrimonti C, Marmiroli N (2018). PCR analysis of experimental and commercial wines by means of nuclear and chloroplast SSRs. European Food Research and Technology 244:2127-2140. https://doi.org/10.1007/s00217018-3121-5

Akkurt M (2012). Comparison between modified DNA extraction protocols and commercial isolation kits in grapevine (Vitis vinifera L.). Genetics and Molecular Research 11(3):2343-2351. https://doi.org/10.4238/2012.August.13.8 
Arroyo-Garcia R, Lefort F, de Andres MT, Ibanëz J, Borrego J, Jouve N, Cabello F, Martinez-Zapater JM (2002). Chloroplast microsatellite polymorphisms in Vitis species. Genome 45(6):1142-1149. https://doi.org/ $10.1139 / g 02-087$

Baleiras-Couto MM, Eiras-Dias JE (2006). Detection and identification of grape varieties in must and wine using nuclear and chloroplast microsatellite markers. Analytica Chimica Acta 563:283-291. https://doi.org/10.1016/j.aca.2005.09.076

Bigliazzi J, Scali M, Paolucci E, Cresti M, Vignani R (2012). DNA extracted with optimized protocols can be genotyped to reconstruct the varietal composition of monovarietal wines. American Journal of Enology and Viticulture 63(4):568-573. https://www.ajevonline.org/content/63/4/568

Briciu D, Pamfil D, Briciu A, Curticiu D, Balazs E, Taoutaou A, Pop I, Cota L (2010). Development of methods for DNA extraction from leaves and must grapes. Bulletin of University of Agricultural Sciences and Veterinary Medicine Cluj-Napoca. Animal Science and Biotechnologies 67(1):1843-1849. https://dx.doi.org/10.15835/buasvmcnasb:67:1-2:5

Cabezas JA, Ibáñez J, Lijavetzky D, Vélez D, Bravo G, Rodríguez V, ... Ruiz-García L (2011). A 48 SNP set for grapevine cultivar identification. BMC Plant Biology 11(153):1-12. https://doi.org/10.1186/1471-2229-11-153

Catalano V, Moreno-Sanz P, Lorenzi S, Grando MS (2016). Experimental review of DNA-based methods for wine traceability and development of a Single-Nucleotide Polymorphism (SNP) genotyping assay for quantitative varietal authentication. Journal of Agricultural and Food Chemistry 64(37):6969-6984. https://doi.org/10.1021/acs.jafc.6b02560

Drabek J, Stavek J, Jaluvkova M, Jurcek T, Frebort I (2008). Quantification of DNA during winemaking by fluorimetry and Vitis vinifera L. specific quantitative. PCR. European Food Research Technology 226:491-497. https://doi.org/10.1007/s00217-007-0561-8

Faria MA, Magalhaes R, Ferreira MA, Meredith CP, Ferreira Monteiro F (2000). Vitis vinifera must varietal authentication using microsatellite DNA analysis (SSR). Journal of Agricultural and Food Chemistry 48:10961100. https://doi.org/10.1021/jf990837h

Garcia-Beneytez E, Maria VM, Joaquin B, Maria CP, Javier I (2002). Application of a DNA analysis method for the cultivar identification of grape musts and experimental and commercial wines of Vitis vinifera L. using microsatellite markers. Journal of Agricultural and Food Chemistry 50(21):6090-6096. https://doi.org/10.1021/jf0202077

Gheorghe RN, Popescu CF, Pamfil D, Ciocirlan CN, Sestras R (2010). Genetic diversity of some Romanian grapevine cultivars as revealed by microsatellite markers. Romanian Biotechnological Letters 15(2):26-31. https://erepository.org/rbl/vol.15/iss.2.s/5.pdf

Hârta MH, Pamfil D, Pop R, Vicaş S (2011). DNA fingerprinting used for testing some Romanian wine varieties. Bulletin of University of Agricultural Sciences and Veterinary Medicine Cluj-Napoca Horticulture 68(1):143-148. https://doi.org/10.15835/buasvmcn-hort:7041

Işçi B, Yildirim H K, Altindisli A (2014). Evaluation of methods for DNA extraction. Journal of The Institute of Brewing 120:238-243. https://doi.org/10.1002/jib.129

Lazareva EG, Gilmanov KKh, Bigaeva AV, Mikhailova IYu, Semipyatny VK, Vafin RR (2020). DNA authentication technologies for product quality monitoring in the wine industry. Food Systems 3(4):11-14. https://doi.org/10/21323/2618-9771-2020-3-4-11-14

Lee A, Jain A (2017). DNA concentration measurement at $260 \mathrm{~nm}$ using Photopette Bio. Tip Biosystems. Application Note.1-3. AN-LS-001-DNA-Measurement. https://tipbiosystems.com/wp-content/uploads/2020/05/ANLS-001-DNA-Measurement.pdf

Lodhi M A, Weeden N F, Reisch B I (1994). A Simple and efficient method for DNA extraction from grapevine cultivars and Vitis species. Plant Molecular Biology Reporter 12(1):6-13. https://doi.org/10.1007/BF02668658

Nakamura S, Haraguchi K, Mitani N, Ohtsubo K (2007). Novel preparation method of template DNAs from wine for PCR to differentiate grape (Vitis vinifera L.) cultivar. Journal of Agricultural and Food Chemistry 55(25):10388-10395. https://doi.org/10.1021/jf072407u

Nazhad NR, Solouki M (2008). Separation of DNA for molecular markers analysis from leaves of the Vitis vinifera. $\begin{array}{llll}\text { Pakistan Journal of } & \text { Biological } & \text { Science } & \text { 11(11):1436-1442. }\end{array}$ https://scialert.net/abstract/?doi=pjbs.2008.1436.1442 
Oganesyants LA, Vafin RR, Galstyan AG, Semipyatniy VK, Khurshudyan SA, Ryabova AE (2018). Prospects for DNA authentication in wine production monitoring. Foods and Raw Materials 6(2):438-448. http://doi.org/10.21603/2308-4057-2018-2-438-448

Pereira L, Guedes-Pinto H, Martins-Lopes P (2011). An enhanced method for Vitis vinifera L. DNA extraction from wines. American Journal of Enology and Viticulture 62(4):547-552. https://www.ajevonline.org/content/62/4/547

Pereira L, Gomes S, Castro C (2017). High Resolution Melting (HRM) applied to wine authenticity. Food Chemistry 216:80-86. https://doi.org/10.1016/j.foodchem.2016.07.185

Savazzini F, Martinelli L (2006). DNA analysis in wines: development of methods for enhanced extraction and real-time polymerase chain reaction quantification. Analytica Chimica Acta 563:274-282. https://doi.org/10.1016/j.aca.2005.10.078

Scali M, Elisa P, Jacopo B, Mauro C, Vignani R (2014). Vineyards genetic monitoring and Vernaccia di San Gimignano wine molecular fingerprinting. Advances in Bioscience and Biotechnology 5(2):142-154. https://doi.org/10.4236/abb.2014.52018

Siret R, Boursiquot JM, Merle MH, Cabanis JC, This P (2000). Toward the authentication of varietal wines by the analysis of grape (Vitis vinifera L.) residual DNA in must and wine using microsatellite markers. Journal of Agricultural and Food Chemistry 48(10):5035-5040. https://doi.org/10.1021/jf991168a

Siret R, Gigaud O, Rosec JP, This P. (2002) Analysis of grape Vitis vinifera L DNA in must mixtures and experimental mixed wines using microsatellite markers. Journal of Agricultural and Food Chemistry 50:3822-3827. https://doi.org//10.1021/jf011462e

Vignani R, Liò P, Scali M (2019). How to integrate wet lab and bioinformatics procedures for wine DNA admixture analysis and compositional profiling: case studies and perspectives. PLoS One 14(2):e0211962. https://doi.org/10.1371/journal.pone.0211962
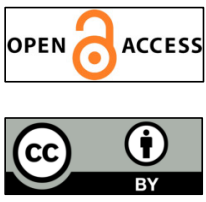

The journal offers free, immediate, and unrestricted access to peer-reviewed research and scholarly work. Users are allowed to read, download, copy, distribute, print, search, or link to the full texts of the articles, or use them for any other lawful purpose, without asking prior permission from the publisher or the author.

License - Articles published in Notulae Botanicae Horti Agrobotanici Cluj-Napoca are Open-Access, distributed under the terms and conditions of the Creative Commons Attribution (CC BY 4.0) License.

(c) Articles by the authors; UASVM, Cluj-Napoca, Romania. The journal allows the author(s) to hold the copyright/to retain publishing rights without restriction. 